\title{
EFFECTS OF SENILE CHANGES AND HYDROCORTISONE. ADMINISTRATION, AS COMPARED WITH CHANGES IN EXPERIMENTAL RUPTURE OF THE ACHILLES TENDON IN RATS
}

\author{
Shahira Youssef, Soheir I. Saleh and Azza S. Soliman \\ Anatomy Department , Facully of Medicine, Ain Shams University
}

\section{INTRODUCTION}

Recent studies have challenged the traditional view that all tendons and ligaments are alike. It is postulated that tendons vary in structure and biochemical composition. Moreover, cach tendon shows regional heterogenicity along its length (Harwood and Amiel, 1992; Vogel et al., 1993). The study of the detailed structure of tendons has gained special attention as it has important clinical implications. Tendons may need to be carefully investigated and selected for particular surgical transfers and joint reconstructions (Benjamin et al., 1995).

The Achilles tendon is of particular interest. since it is the strongest tendon in the human body with a tensile length of $50-100 \mathrm{~N} / \mathrm{mm}$. It is formed from the joining of the two tendons of soleus and gastrocnemius (Williams et al., 1995). Despite of its strength, the Achilles tendon is the most frequently ruptured tendon in the human body. Tendon fibers begin to disrupt after length increase of $3-4 \%$ and rupture after an increase of $8 \%$. Rupture is common in males in the fourth decade, it usually occurs between $2-6 \mathrm{~cm}$ from its insertion into the calcaneus. The greatest risk of rupture is when the tendon is obliquely loaded and the muscke is contracting maximally, as a result of pushing ofl with feet against rcsistance (Cetti et al., 1993 \& Maccellan and Maffulli, 2002).

Moreover, rupture is a common sequence of steroid therapy (Hersh and Heath, 2002), quinolone antibiotic therapy (Poon and Sundaram, 1997) levoflaxacin and other fluoroquinoiones (Mathi et al., 2003). Rupture of the Achilles tendon has been also noticed after renal transplantation (Hestin et al., 1993) and in cases of chronic obstructive pulmonary discases (Khurana et al., 2002). Furthermore, in- 
creased activity and velocity sports might increase the incidence of rupture (Mazzone and McCue, 2002).

The exact etiopathogenesis of Achilles tendon rupture is unknown, but it is claimed that both ruptured and tendinopathic tendons show evidences of histological degeneration compared to the normal tendons (Tallon et al., 2001). Understanding the anatomy and histology of the ruptured Achilles tendon and contiguous structures is essential in the diagnosis and treatment of Achilles tendon injuries (Schepsis et al., 2002).

Thus the purpose of the present study was to determine the detailed ultrastructure of the Achilles tendon in rat. Moreover, it aimed at illustrating and comparing the degenerative changes resulting from both aging and following steroid administration with the degenerative changes in the expcrimentally ruptured tendon.

\section{MATERIALS AND METHODS}

Thirty male albino rats were obtaincd from the Research Unit and Bilharzial Research Center of Faculty of Medicine, Ein Shamus University. Animals were divided into four groups.

\section{Group I :}

Included 5 rats aging 3 - 4 months (adult group). They were used as a control group.

\section{Group II :}

Included 5 rats aging 18 - 24 months (Senile group). They were used to study the age related changes in the Achilles tendon.

\section{Group III :}

Included ten adult rats of which seven rats received $0.50 \mathrm{ml}(25 \mathrm{mg})$ of hydrocortisone (Hydrocortisone hemisuccinate, Rousscl) intraperitoneally for three weeks. Three rats reccived $0.5 \mathrm{ml}$ of vehicle intrapcritoneally for the same duration and were used as controls for this group.

\section{Group IV :}

Included ten adult rats. seven of which were anaesthetized by ether inhalation. Their right hind limbs were extended, shaved and fixed. A longitudinal incision was performed in back of the leg and the skin was reflected. Gastrocnemius muscle and 
tendoachilles were identified. The tendon was traced and dissected. Achilles tendon was transected mid way between musclo-tendinous junction and the site of insertion and left without suturing (Rickert et al., 2001). Skin was sutured and cleaned with antiseptic. Animals were left for three weeks. The remaining three rats were anaesthetized but without surgical interference and were used as controls for this group.

At the end of the experiment, all animals were killed by cervical dislocation. Achilles tendons were dissected and specimens were taken from the tendons away from the calcaneus. Specimens were cut into small pieces, fixed in $4 \%$ glutraldehyde then washed in phosphate buffer and post fixcd in $1 \%$ osmium tetraoxide. Fixation was followed by dehydration and embedding in epoxy resins. Semithin sections (1 um) were stained with toluidinc bluc. Ultrathin sections were stained with uranyl acetate and lead citrate according to Reynolds (1963), examined and photographed using transmission electron microscope (Philips CM 100).

\section{RESULTS}

\section{The control groups :}

Examination of the semithin sections of Achilles tendon of group I and the controls of group III and IV showed that Achilles tendon consisted of dense regular, elongated collagen fibers with parallel orientation (Fig. 1). However, few fibers were partially interwoven particularly those in close vicinity to the fibroblasts which appeared trapped between the collagen fibcrs. The fibroblasts were aranged in longitudinal rows within the tendons but few single fibroblasts were observed (Fig. 1).

Ultrastructural examination revealed that the collagen fibrils had uniform thickness and were seen either in striated or in cross sectioned forms (Figs. 2, 3). The fibroblasts possessed elongated euchromatic nuclei of moderate condensation of chromatin and the nucleolus was not prominent (Fig. 2). Fine cytoplasmic processes were seen extending from the fibroblasts and ramifying throughout the tendon (Figs. $2,3)$. The cytoplasmic processes contained extensive rough endoplasmic reticulum and few Golgi complexes (Fig. 3).

\section{Group II :}

Examination of the semithin sections of group II revealed that Achilles tendon of the senile rats had less dense, looscly packed collagen bundles. The fibrtblasts were irregularly arranged and frequently had crenated vesicular nuclei (Fig. 4). Most 
of the fibroblasts were surrounded by wide pale areas of depleted fibers. Few cells with dark fusiform nuclei were intcrposed between the collagen fibers (Fig. 5).

Ultrastructural study clarified that the collagen fibrils were loosely compacted as compared with the adult group. Occasionally localized areas of complete degeneration were encountered (Fig. 6). Although the condensation of nuclear chromatin of the fibroblasts was unaltered, yet the cytoplasmic processes contained few areas of degeneration slightly dilate cisterns of rough endoplasmic reticulum and numerous lysosomes (Figs. 6, 7). Some of the tendon cells had indented irregular nuclei and showed increased chromatin condensation. In such cells, the cytoplasm contained restricted organelles apart from few cisterns of rough endoplasmic reticulum, collections of polyribosomes and numerous small vesicles (Fig. 8).

\section{Group III :}

Examination of the semilhin sections of group III demonstrated that Achilles tendons of rats which received hydrocortisone for threc weeks had noticeable vascularity. Numerous small congested blood vessels invaded the collagen fibers. Masi cells were frequently noticed (Fig. 9). Moreover, wide areas of cxudation and multiple vacuoles of variable sizes were encountered inbetween the collagen fibers (Fig. 9).

Ultrastructural examination demonstrated that the collagen fibrils were irregular in arrangement and widely separated. Most of the fibrils were thin and partially fragmented (Figs. 10.11,12). Mast cells were noticed inbetween the collagen fibrils (Fig. 11). The fibroblasts had crenated nuclei with deeply condensed chromatin and depleted cytoplasm (Fig. 10). The cytoplasmic processes exhibitcd wide areas of degeneration, scanty cisterns of rough endoplasmic reticulum, numerous lysosomes and multiple small vesicles (Figs. 11. 12).

A characteristic feature was the presence of groups of altered tendon cells which occurred cither single or in clusters. The cells were separated by amorphous homogeneous strips of extra-cellular matrix of variable electron density (Fig. 13). Most of the cells had oval indented nuclei with highly condensed chromatin (Fig. 13). Some cells were binucleated their cytoplasm elaborated small arched processes and contained few organelles (Fig. 14).

\section{Group IV :}

Examination of the semithin sections of the cxperimentally ruptured tendons showed that the Achilles tendon was vascular and hypercellular (Figs. 15, 16, 17). 
The tendons were infiltrated by numerous swollen, rounded or oval cells irregularly arranged between the collagen fibers (Figs. 15, 16). The cells had large rounded euchromatic nuclei and prominent nucleolus. Numerous cells showed different mitotic figures. The nuclei were surrounded by granular cytoplasm (Figs. 15, 16).

Ultrastructural examination clarified that the collagen fibrils lost their regular pattern of arrangement. Most of the fibrils were markedly interrupted and widely separated. Moreover, wide areas of degeneration were observed (Fig. 18). Inspite of the marked interruption of the collagen fibrils, few focal areas of condensed collagen fibrils were observed close to the tendon cells (Fig. 19). The fibroblasts exhibited different forms, of which, some had elongated nuclei of moderatc condensation of chromatin but the cytoplasmic processes contained dilated cisterns of rough endoplasmic reticulum with detached ribosomes (Fig. 20). Other fibroblasts had rounded nuclei and their cytoplasmic processes were highly degenerated and contained few ill-defined cisterns of rough endoplasmic reticulum (Fig. 20). Among the degenerated collagen fibrils few fibroblasts had irregular nuclear membrane, prominent large nucleolus and degenerated ill-defined cytoplasmic processes (Fig. 19). 


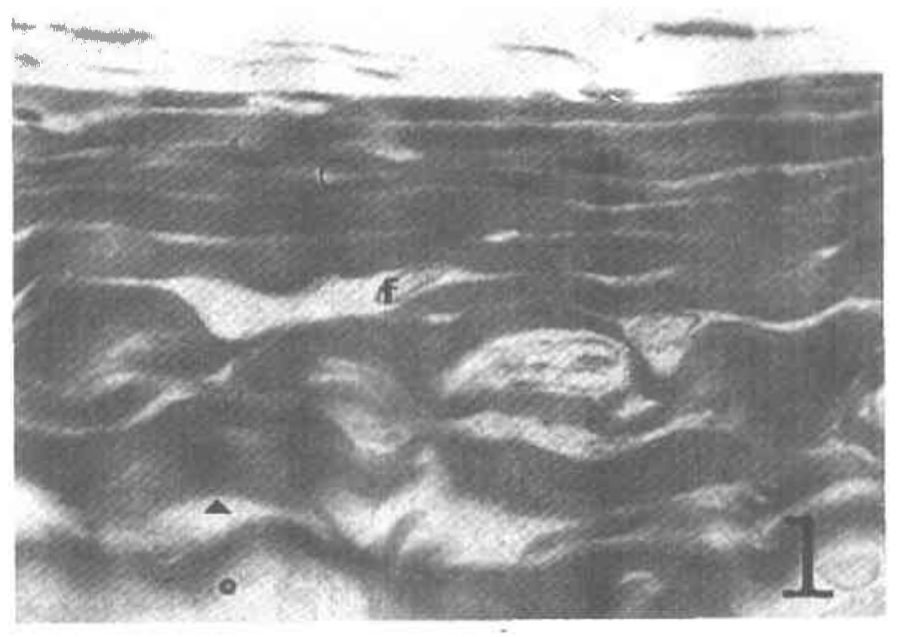

Fig. (1) : A photomicrograph of a semithin section of the Achilles tendon of control group showing regular dense collagen fibers (c). Notice the interwoven fibers $(\$)$ and the fibroblast $(f)$ wilh alongated nuclei.

(Toulidine blue; $\mathrm{x}$ 1000)

Fig. (2) : Transmission electron micrograph of the Achilles tendom of the control group showing collagen fibriles (f) in transverse and longitudinal sections. Notice the euchromatic elongated nucleus $(N)$ and the cytoplasmic processes ( $\mathrm{P}$ ).

(Uranyl acetate \& lead citrate; $x$ 9800)

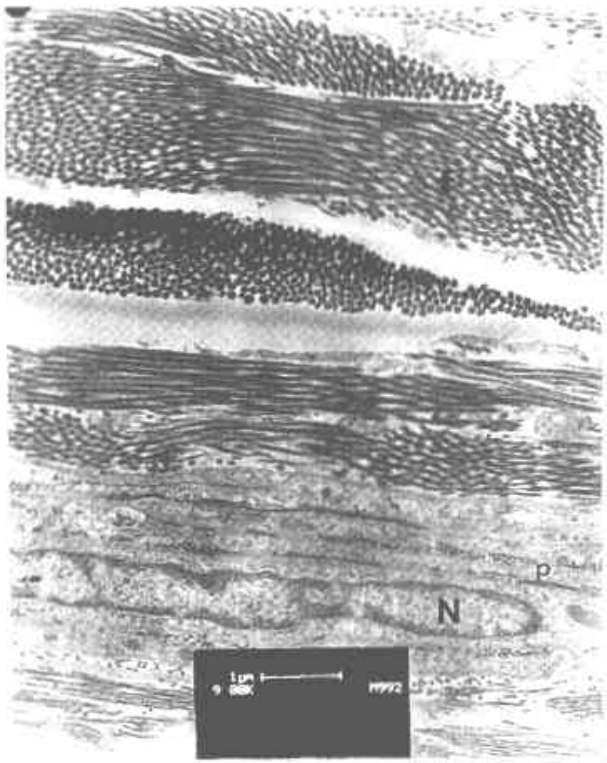




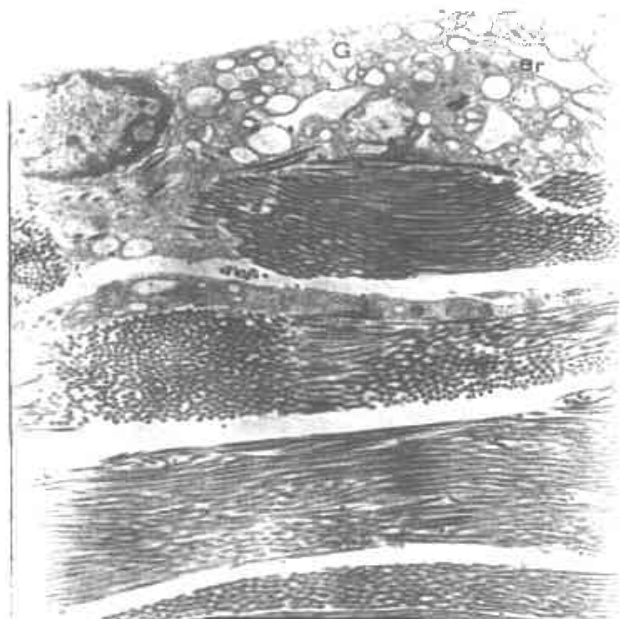

Fig. (3) : 'transmission clectron microngraph of the Achilles tendon of the control group showing cyloplasmic processes with rough endoplasmic reticulum (er) and Golgi consplexes (G).

(Uranyl acetate \& lead citrate; $7780(0)$

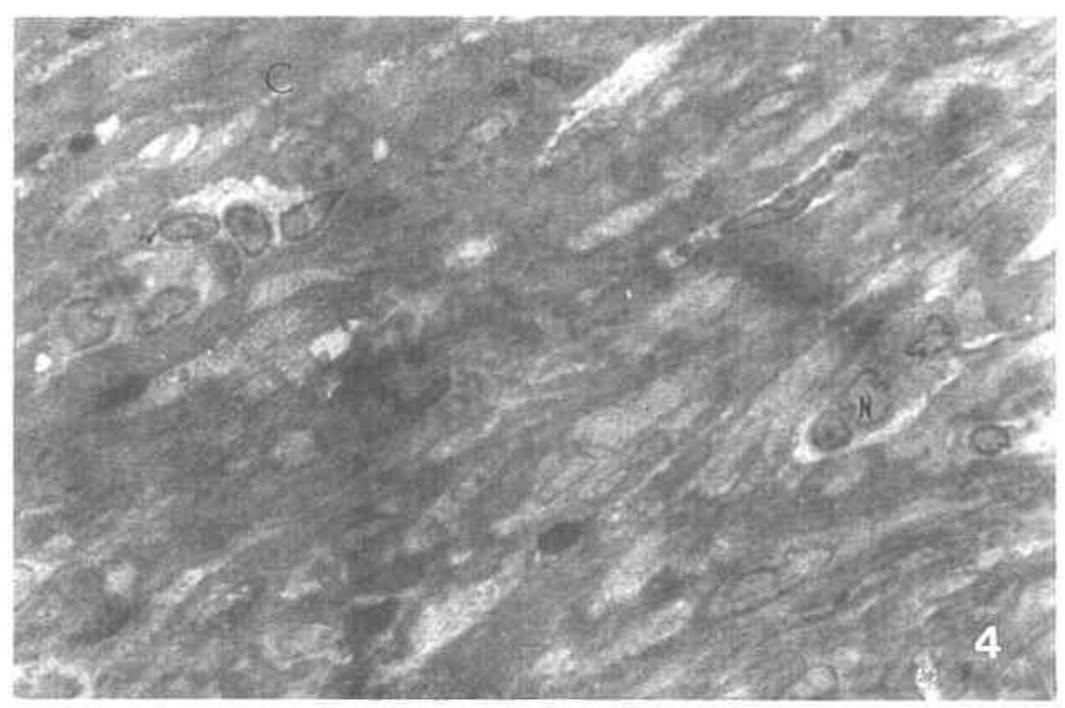

Fig. (4) : A pholomicrograph of a semithin section of the Achilles tendon of the senile group showing lonsely packed collagen bundles (C). Notice the crenated nuclei $(\mathrm{N})$ of the fibroblusts.

(Toulidine blue: $\times 1000$ ) 


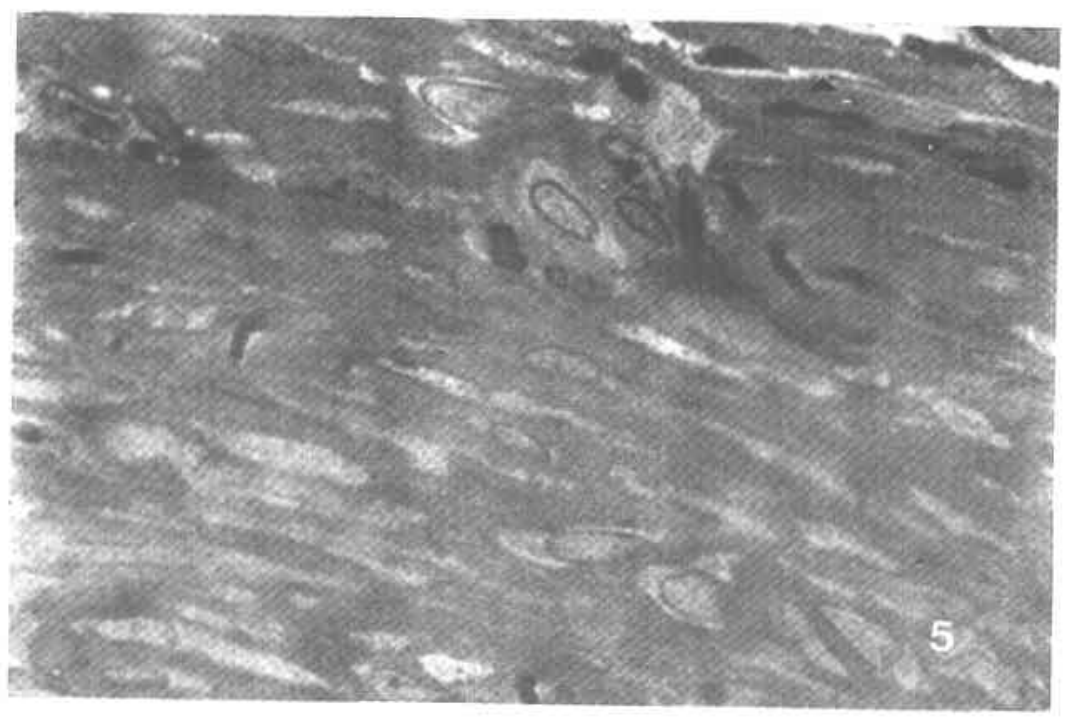

Fig. (5) : A photomicrograph of a semithin section of the Achilles tendon of the senile group showing pale areas of depleted fibers $(\uparrow)$. Notice the dark rounded
or fusiform nuclei (n).

(Toulidine blue: $\times 1000$ ) 


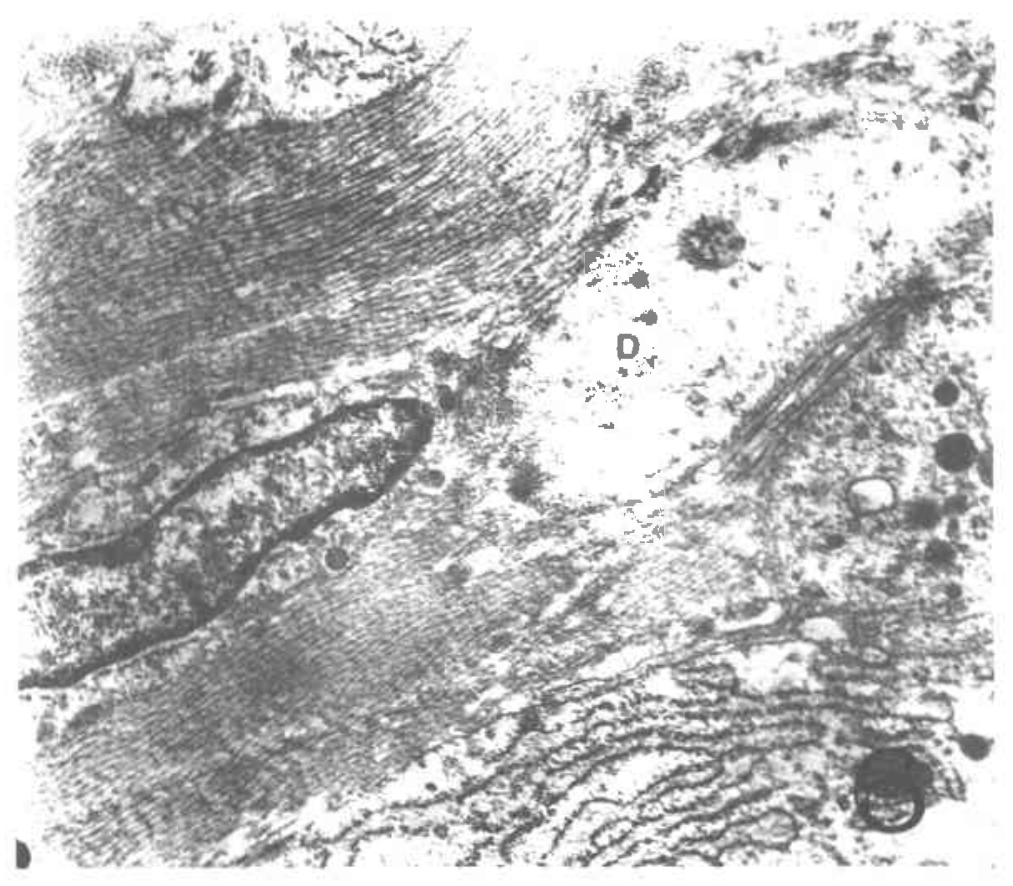

Fig. (6) : Transmission electron micrograph of the Achilles tendon of the senile group showing localized area of complete degeneration (D). Notice the lysosomes (L).

(Uranyl acetate \& lead citrate; $x$ 11,000) 


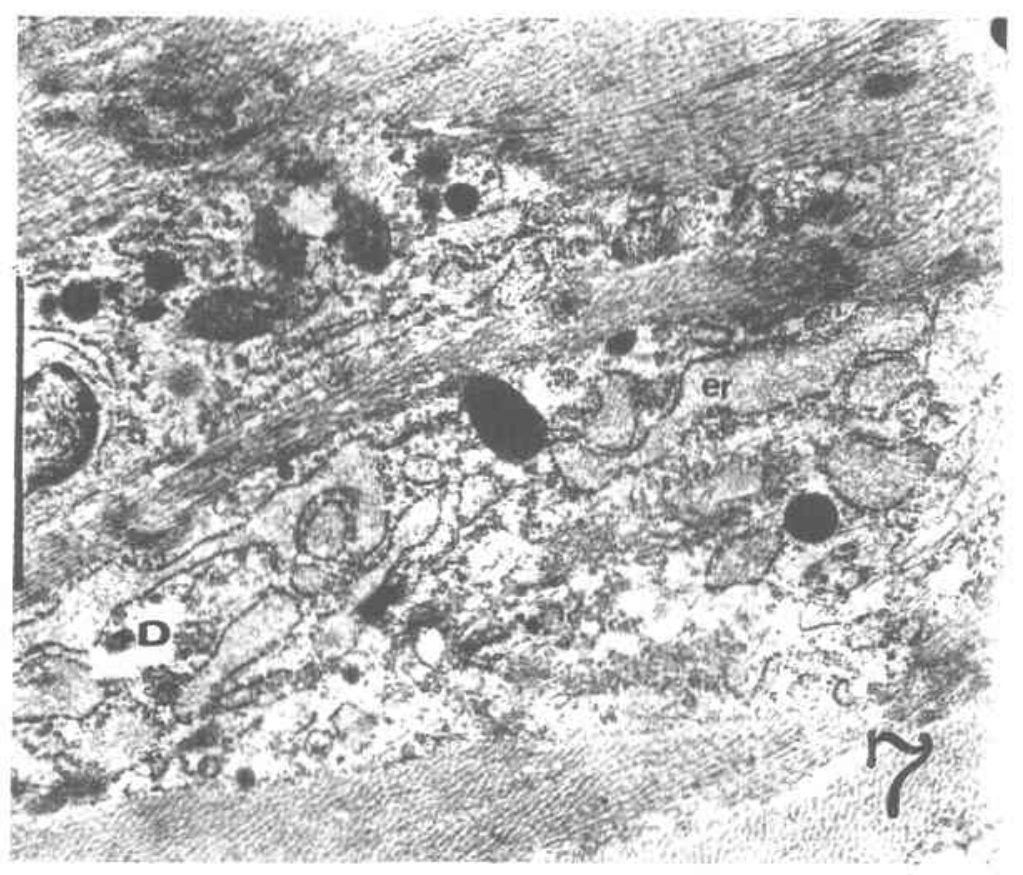

Fig. (7) : Transmission electron micrograph of the Achilles tendon of the senile group showing cytoplasmic processes with areas of degneration (D). partially dilated irregular cisterns of rough endoplasmic reticulum (er) and numerous lysosoncs (L).

(Uranyl acetate \& lead citratc; $\mathrm{x} 11.500$ ) 


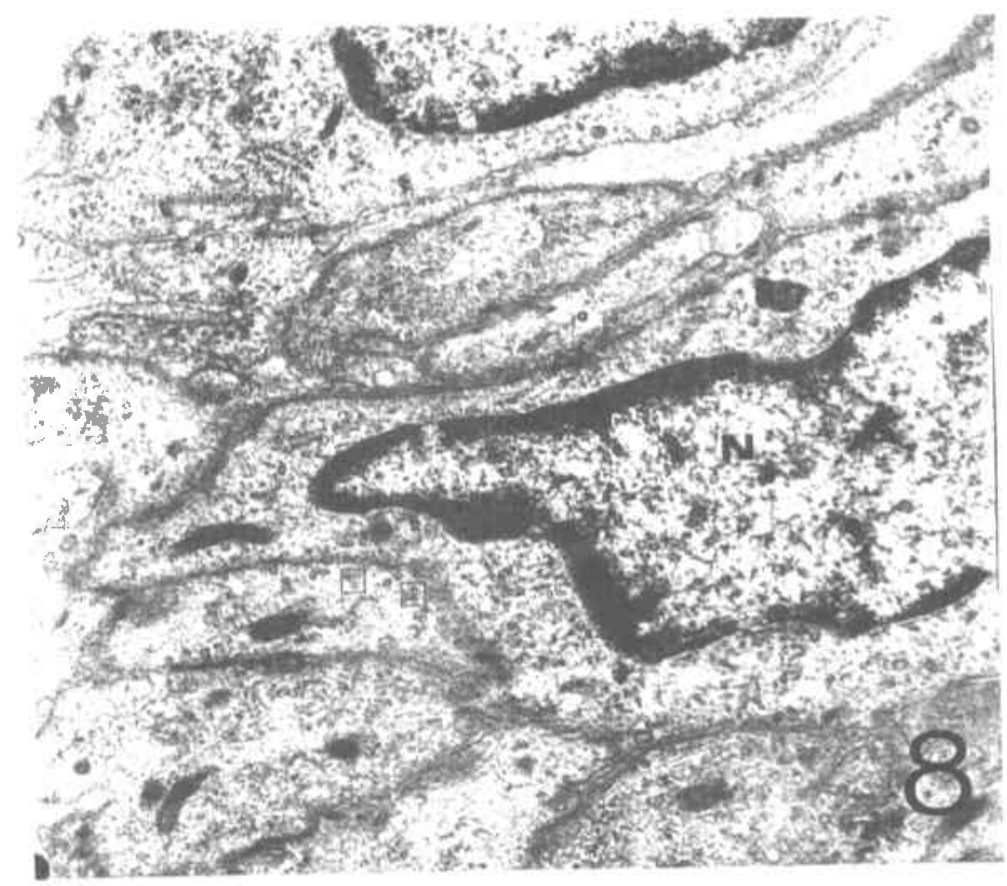

Iig. (8): l'ansmission electron micrograph of the Achilles tendon of the senile group showing nucleus (N) with increased chromatin condensation and cytoplasm with restricted organdles. Notise the numerous vesicles (

(Uranyl acetate \& lead citrate; $x$ 11.000) 


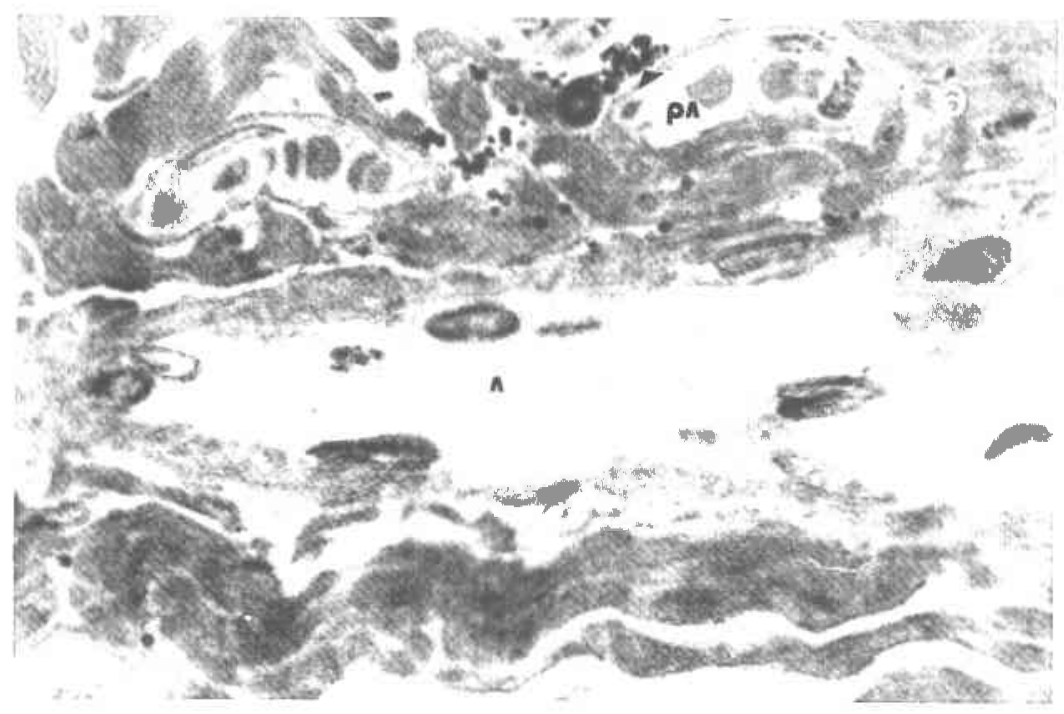

Fig- (9) : $\wedge$ photomicrograph of a semithin section of the Achilles tendon from the group which received hydrocortisone showing numerous small blood vessels (bv), mast cell infiltration (\$). Notice the exudation (E) and the multiple vacuoles (V).

(Toulidine blue; $x$ 1000) 


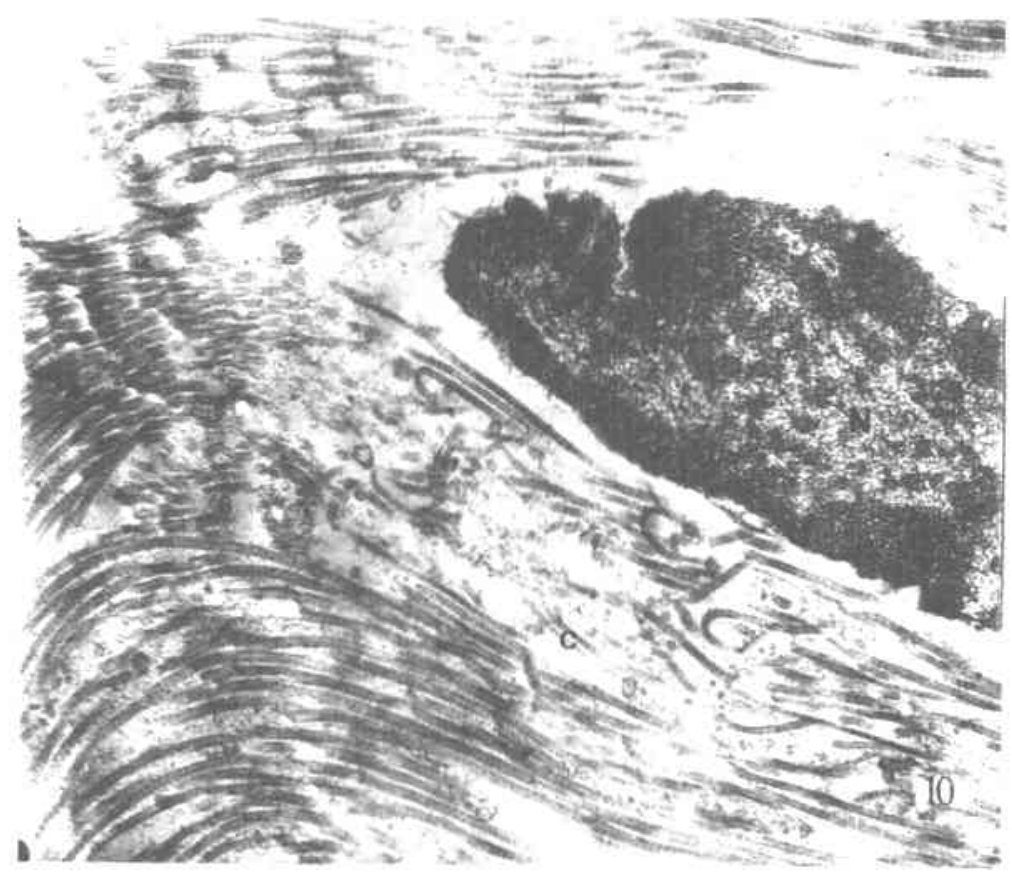

Fig. (10) : Iransmission electron micrograph of the Achilles tendon from the group which received hydrocortisone showing irtegular artangement of collagen fihrils (c). Notice the crenated nucleus $(\mathbb{N})$ with de'oply condensed chromatin.

(Uranyl acetate \& lead citrate; $x$ 15.000) 


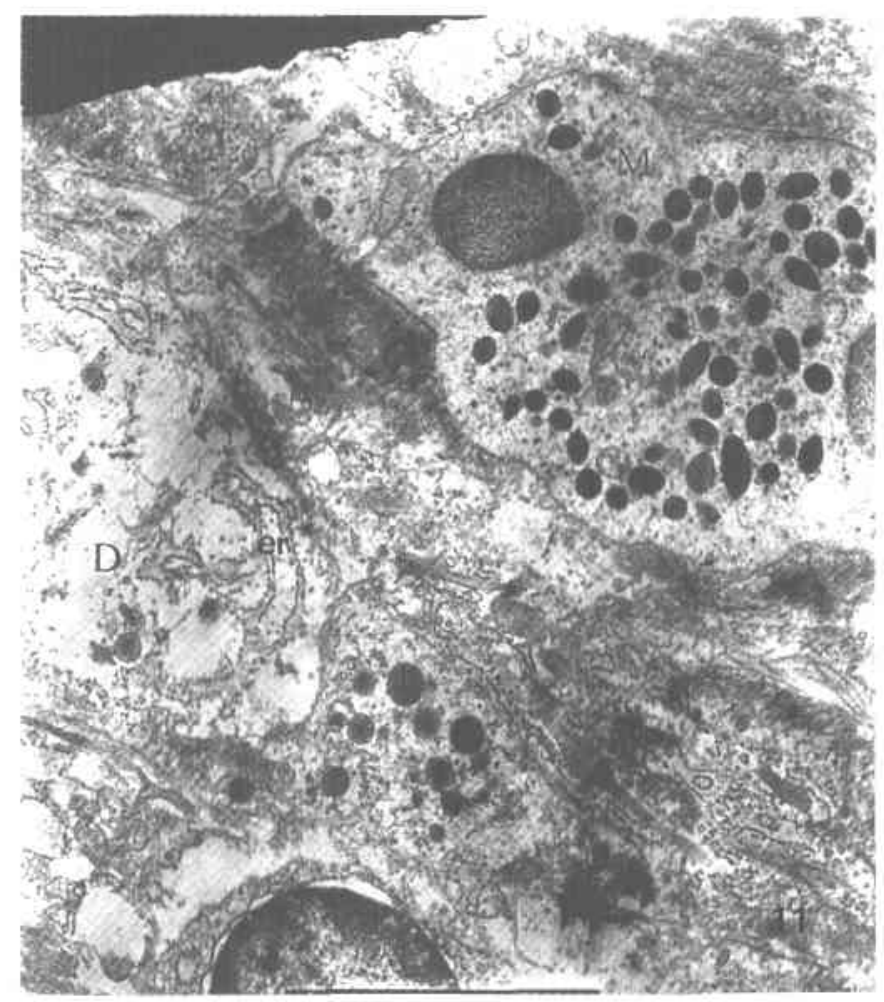

Fig. (11) : Transmission electron micrograph of the Achilles tendon from the group which received hydrocortisone showing cyloplasmic process with wide areas of degeneration (D), scanty cistems of rough endoplasmic reticulum (er) and numerous lysosomes $(\mathrm{L})$. Notice the mast cell $(\mathrm{M})$.

(Uranyl acetate \& lead citrate; $x$ 5200) 


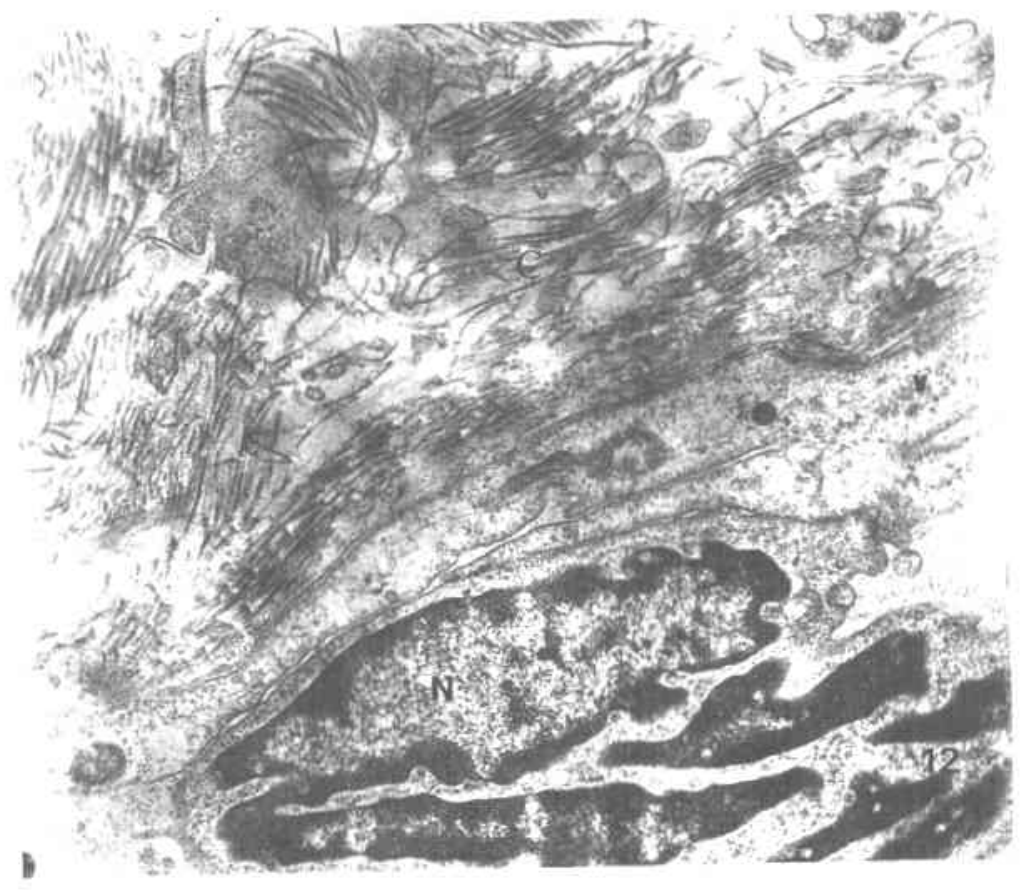

Fig. (12): Transmission electron micrograph of the Achilles tendon from the group which received hydrocortisone showing partially fragmented thin collaggr fibrils (C). Notice the fragmented nuclei with highly condensed chromatin (N) and the small vesicles (V).

(Uranyl aceate \& lead citrate: $x$ 8000) 


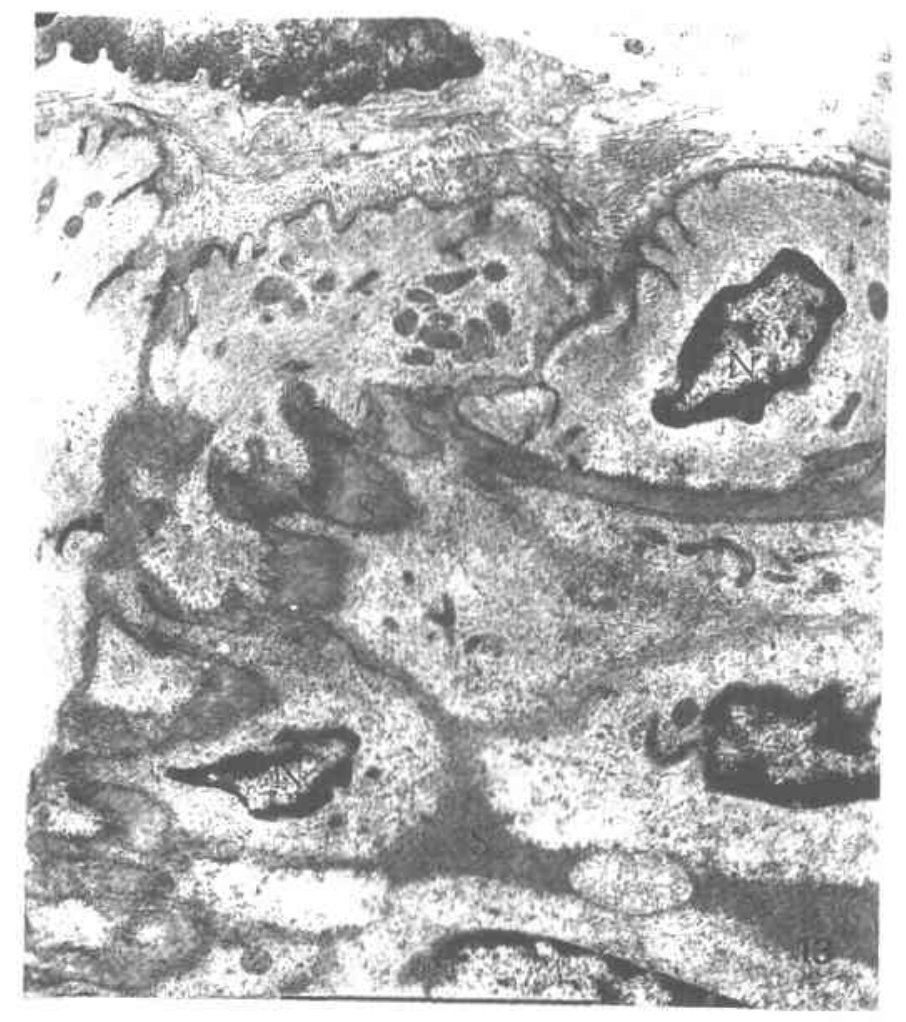

Fig. (13) : Transmission electron micrograph of the Achilles tendon from the group which received hydrocontisone showing the oval indented nucleus with highly condensed chromatin $(N)$ and the amorphous strips of extracellular matrix (S).

(Uranyl acetate \& lead citrate; $x$ 6000) 


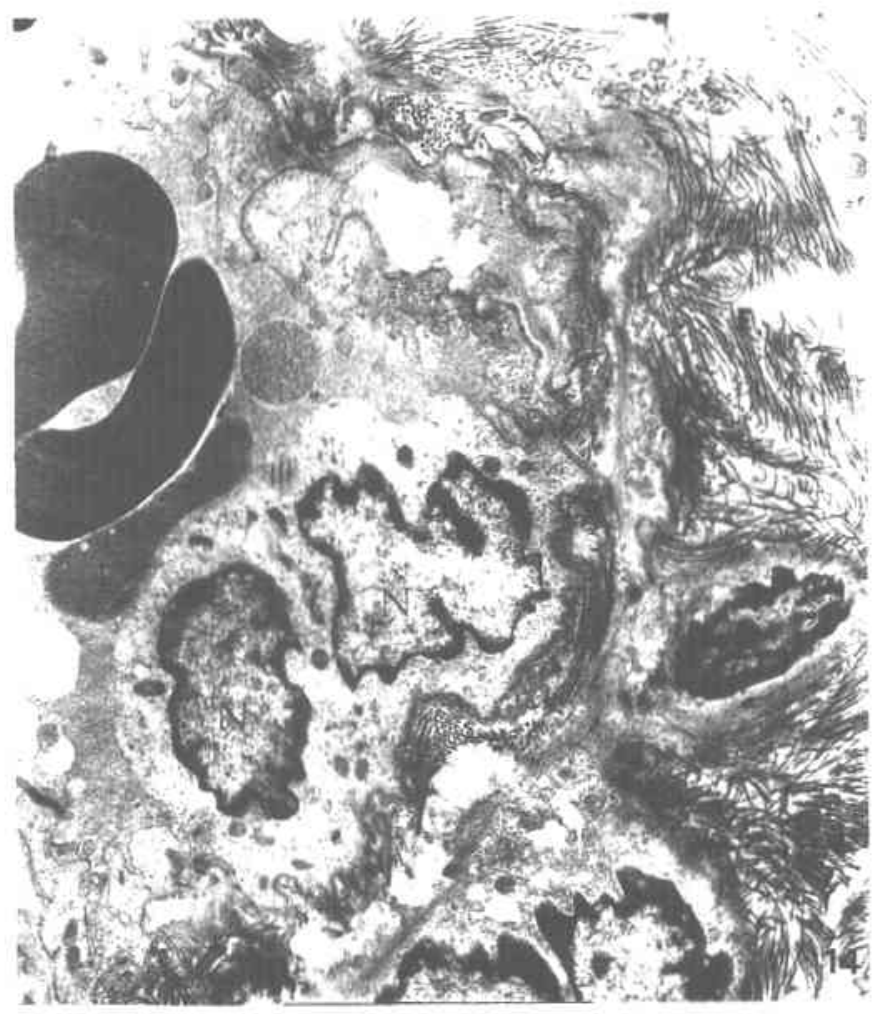

Fig. (14) : Transmission electron micrograph of the Achilles tendum from the group which received hydrocortisone showing binucleated cells, chentitil nucleus $(\mathrm{N})$ and disorganized collagen fibrils (F). Notice the presence of red bluxd cells (R).

(Uranyl acetate \& lead citrate; $x$ 5200) 


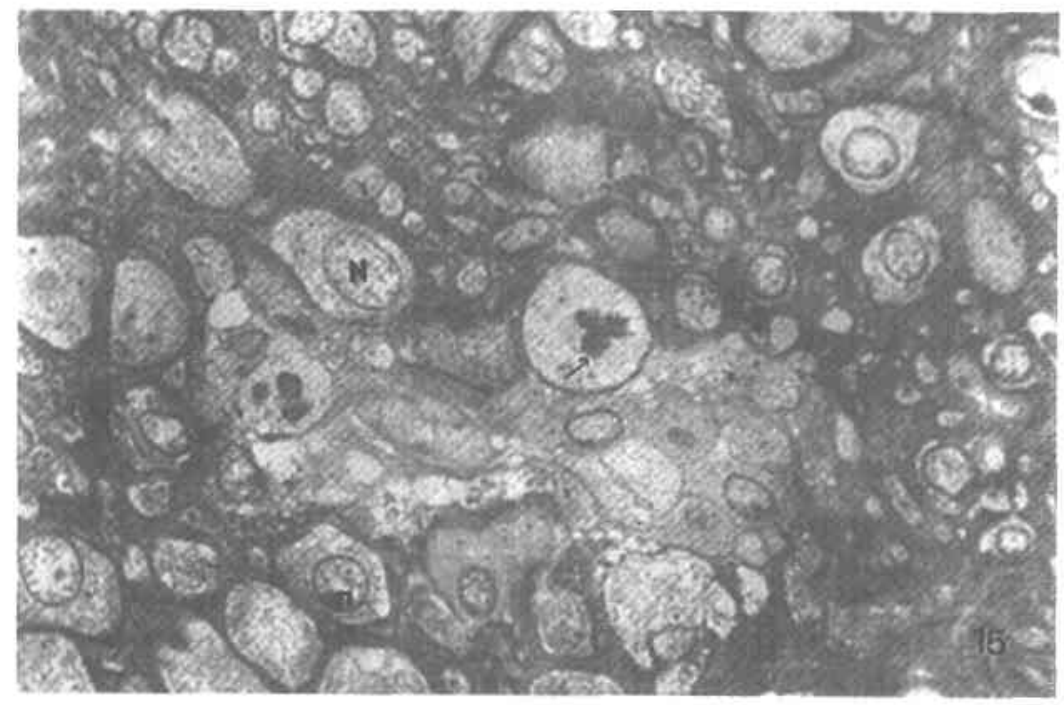

Fig. (15) : A photomicrograph of a semithin section of the Achilles tendon from the experimentally ruptured group showing rounded swollen, cells with euchromatic nucleus $(\mathrm{N})$. Notice the mitotic figure $(\mathrm{T})$ and the nucleolus $(\mathrm{n})$.

(Toulidine blue; $\mathrm{x}$ 1000) 


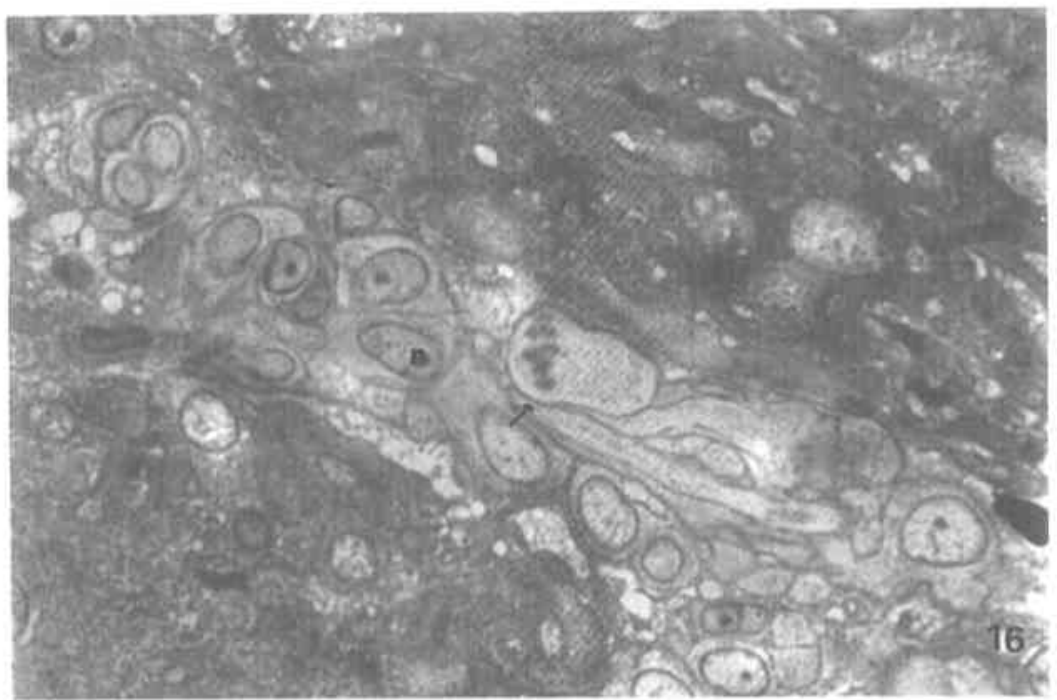

Fig. (16): A photomicrograph of a semithin section of the Achilles tendon from the experimentally ruptured group showing large cell with mitotic figure $(\uparrow)$. Notice the nucleolus (n).

(Toulidine blue; $x$ 1000) 


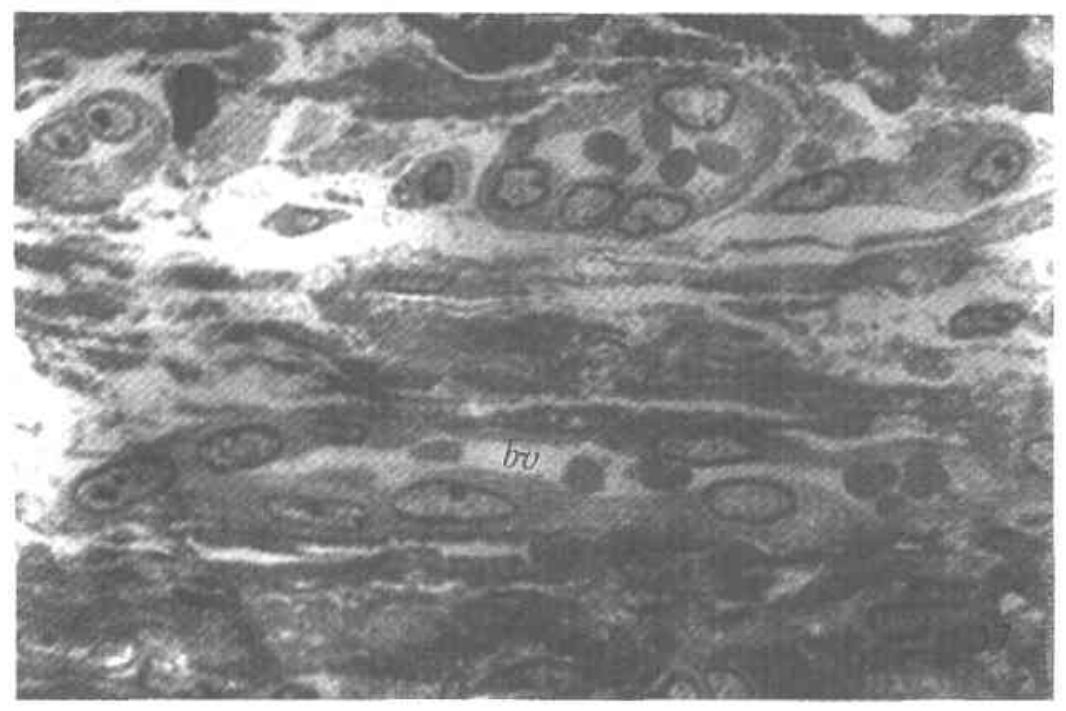

Fig. (17) : A photumicrograph of a semithin section of the Achilles tendon from the experimentally ruptured group showing numcrous blood vessels (bv).

(Toulidine blue; $\times$ 1000) 


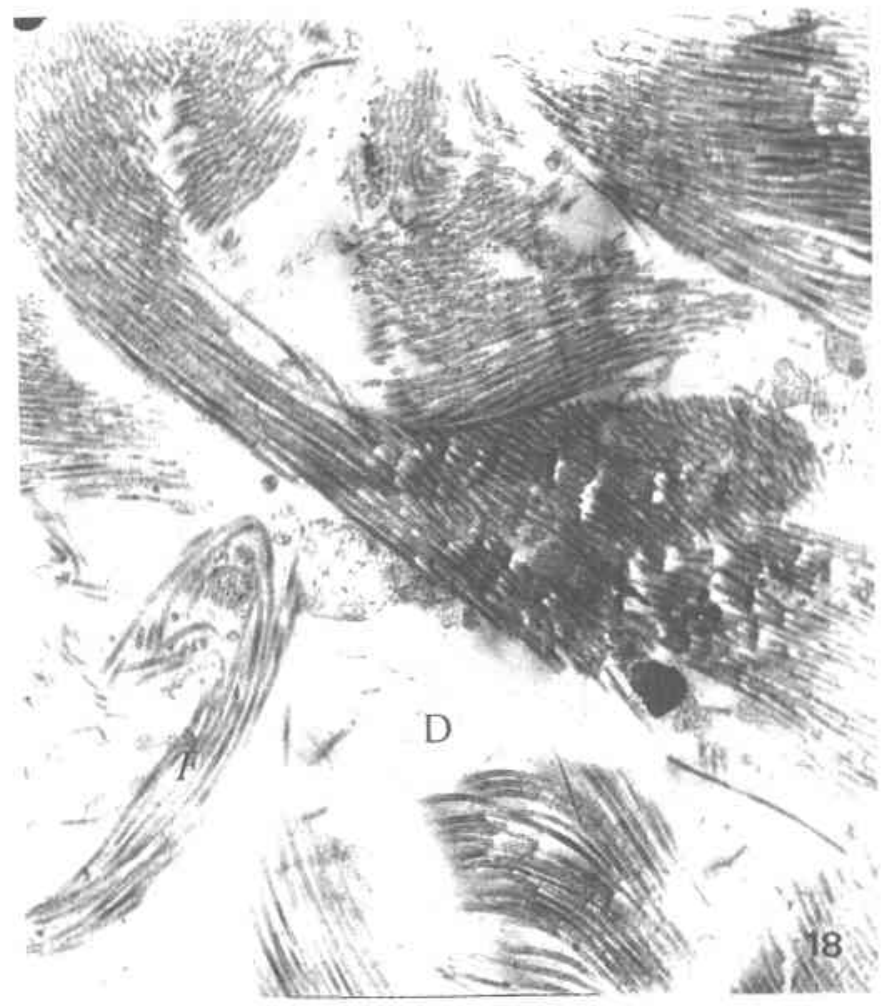

Fig. (18): Transmission electron nicrograph of the Achilles tendon from the cxperimentally ruptured group showing marked intermption and wide separation of the collagen fibrils ( $\mathrm{F}^{\mathrm{F}}$. Notice the wide areas of degeneration (D).

(Uranyl acetate \& lead citrate; $x$ 8900) 


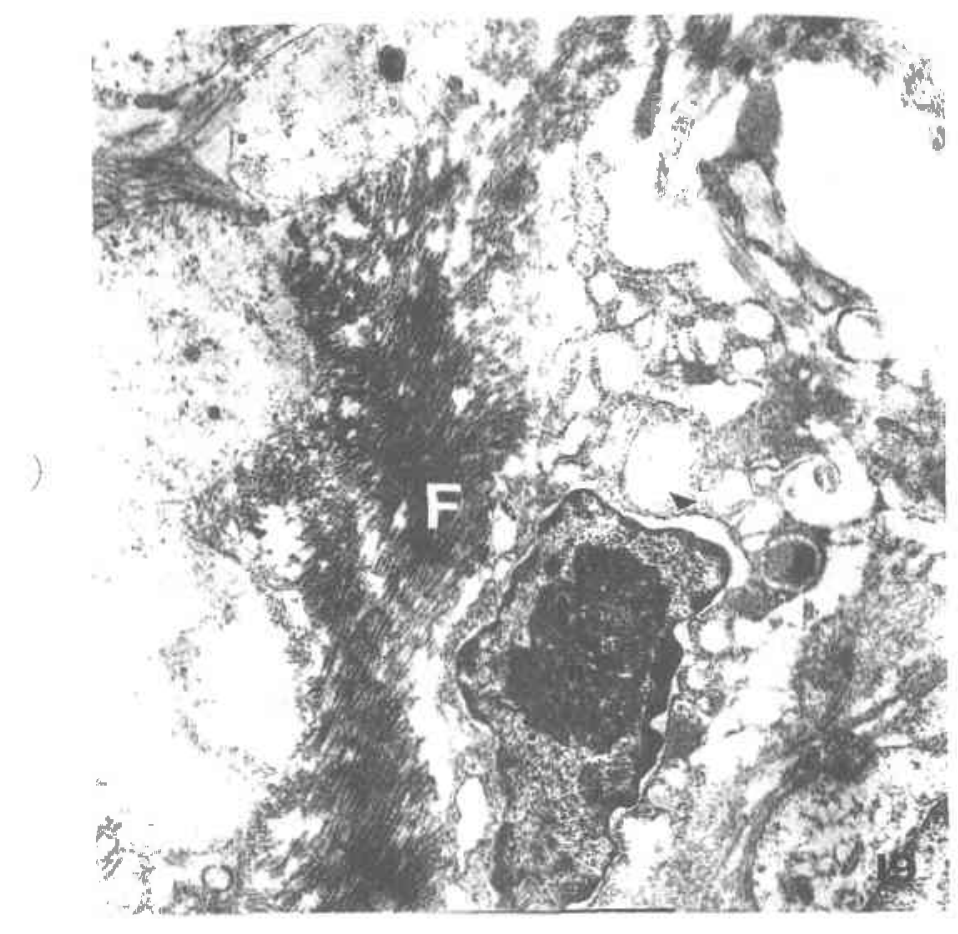

Fig. (19) : Transmission electron micrograph of the Achilles tendon from the experimentally ruptured group showing the marked condensation of the collagen fibrils $(F)$. Notice the fibroblast with irregular nuclear membrane ( $\uparrow$ ) prominent nucleolus ( $\mathrm{n}$ ) and degenerated cytoplasmic process.

(Uranyl acetate \& lead citrate; x 8900) 


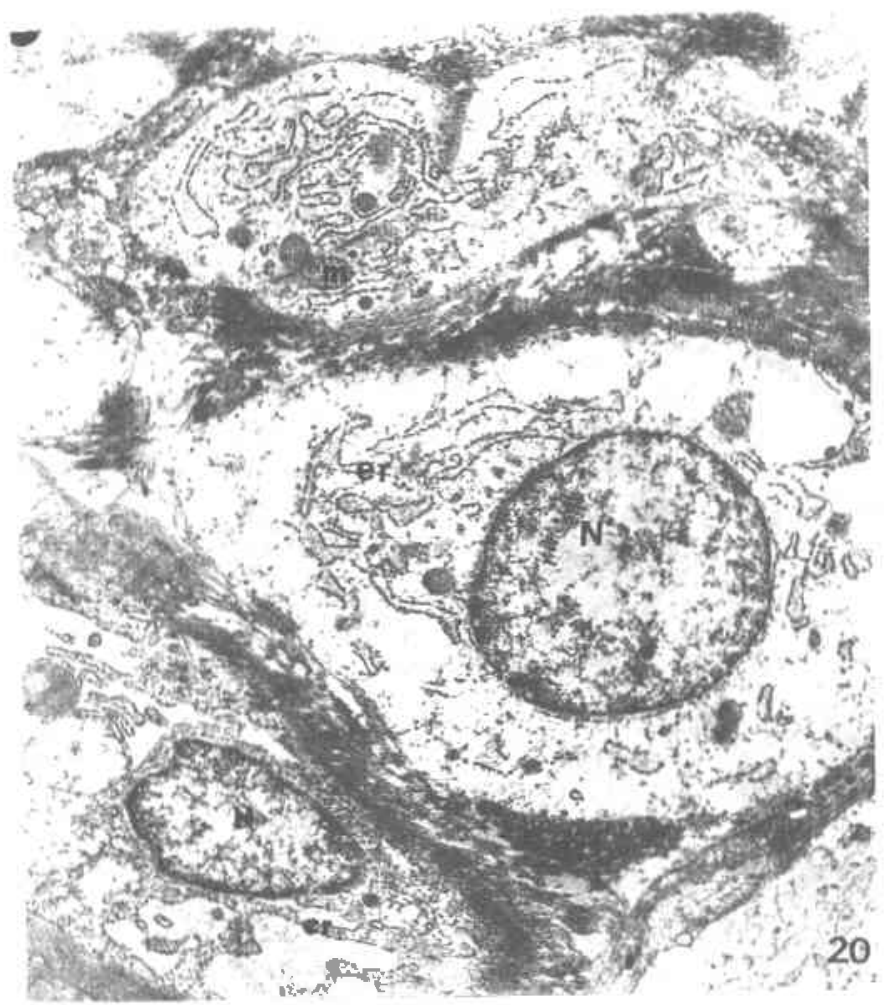

Fig. (20) : Transmission electron micrograph of the Achilles iendon from the experimentally ruptured group showing a fibroblast with elongated nucleus (N) and cytoplasmic processes with dilated cistems of rough endoplasmic reticulum (er). Notice the fibroblast with rounded nuclei $\left(\mathrm{N}^{\circ}\right)$ and cytoplasmic processes with ill defined cistems of rough endoplasmic reticulum (er).

(Uranyl acetate \& lead citrate; $x$ 5200) 


\section{DISCUSSION}

The present study demonstrated that the Achilles tendon had the typical features of tendons. It consisted of dense, regular elongated collagen fibers running in longitudinal and transverse directions. Few collagen fibers were interwoven particularly those in close vicinity to the fibroblasts. The significance of the interwoven fibers is unclear; it could be purely mechanical preventing the tendon from splaying apart when it is under compression, or might be organized to control the swelling of the large proteoglycans of the collagen matrix (Benjamin et al., 1995).

The present work clarified that the fibroblasts were trapped in between the collagen fibers. They were regularly arranged in longitudinal rows, but few single fibroblasts wcre noticed. The cellular organization probably could arise as a consequence of deposition of the oriented collagen matrix (Brik and Zycband, 1994). The intimate association of fibroblasts and collagen fibers could help in the coordination of functions. Fiber bundles perform the force transmission function while the cells maintain and modify the fiber bundles (Ralphs et al., 1998).

In the present study, ultrastructural examination further demonstrated that the fibroblasts had clongated euchromatic nuclei. Numerous cytoplasmic processes were extending from the fibroblasts and ramifying throughout the tendons. The processes had extensive rough endoplasmic reticulum and few Golgi complexes. The cytoplasmic processes probably represent a way of contact between the tendon cells and consequently could play a role in cell communication and coordination of functions (McNeilly et al., 1996).

The present work revealed that aging. hydrocortisone administration and experimental rupture caused various degencralive changes. The Achilles tendon is vulnerable to injury because of its limited blood supply and the combination of forces to which it is subjected. Disregulation of autonomic transmitters in hypovascularized tissues subjected to repetitive mechanical Inad may contribute to tissuc hypoxia leading to degencration or even rupture of the tendons and ligaments (Ackermann et al., 2001).

In the present study, the age-associated changes were present in both the collagen fibers and the fibroblasts. The fibers were less dense and loosely packed. Moreover, localized areas of complete degeneration were observed. The morpholog. ical changes encountered in the collagen fibers in the present study coincides with the pronounced changes in the collagen fiber composition with aging and appearance of collagen type II noticed by Ralphs et al. (1991). 
Regarding the fibroblasts. the cells were irregularly arranged and surrounded by areas of depleted collagen fibers. The nuclei were occasionally crenated and the cyloplasmic process contained areas of degeneration and numerous lysosomes. Such degencrative changes are suggestive of low secretory activity of fibroblasts and could encounter for the decrease in the glycosaminoglycan of the collagen matrix noticed in scnile rats by Benjamin et al. (1991).

Morcover, the present study revealed that in senile rats, some tendon cells exhibited dark condensed nuclei. Ultrastructural studies clarified that these cells had irregular indented nuclei of high chromatin condensation. Their cytoplasm had restricted organelles apart of numerous small vesicles and collections of polyribosomes. These are probably degenerated fibroblasts or inactive fibroblasts. The vesicles present in such cells might be involved in the initiation of calcification of senile tendons (Benjamin et al., 1991). The degenerative changes noticed in the present study in the collagen fibers and fibroblasts might explain the increased incidence of rupture of Achilles tendon with aging noticed by Mazzone and McCue, (2002).

In the present work, it was evident that after hydrocortisone administration for three weeks, the Achilles tendon presented noticeable vascularity. The blood vessel invasion is probably triggered by the degenerative changes in the tendon. Such changes enhance neoangiogenesis in the Achilles tendon to increase blood flow and improve the nutrition (Friedrich et al., 2001). The present study revealed that the blood vessel invasion was associated with ccllular infiltration particularly with mast cells. The presence of mast cells indicates the occurrence of intlammation (Junqueira and Carneiro, 2003).

The degenerative changes following hydrocortisone administration involved the collagen fibers. They were irregularly arranged and widely separated. Most of the fibres were thin and partly fragmented. The degeneration of collagen fibers could encounter for the spontaneous and even bilateral rupture of Achills tendon in patients with long term oral or injected steroid therapy (Hersh and Heath, 2002). Generally. the effects of steroids are dependent on the route of administration. The mode of steroid delivery might be as important as the actual cffects of the drug on the histological and biochemical properties of the tendon. It is claimed that steroid injection had the most deleterious effects (Martin et al., 1999).

Furthermore, in the present study following hydrocortisone administration. most of the tendon cells werc altered. The altered cells existed either in clusters or in a single form and were separated by amorphous homogeneous stripes of extracellular matrix. The cells exhibited oval nucke with highly condensed 
chromatin. Moreover, binuculcated cells were noticeable. The cytoplasm elaborated multiple small rounded processes and contained few organelles. Various modification have been reported in tendon cells following injury, including even transformation into cartilage-like cells through activation of chondrionductive processes (Rickert et al., 2001) or modification into myofibroblast (Moyer et al., 2003). The cell modification and the appearance of the wide homogeneous extracellular matrix might promote and aid healing or counterbalance the disorganization of the collagen fibcrs (Moyer et al., 2003).

The present study demonstrated that experimcntally ruptured tendons presented marked hypercellularity and signs of vascularization on the expense of the degenerated, interrupled collagen fibers. The increased vascularity of ruptured tendons was noticed by Maffulli et al. (2002). It was postulated that a vascular endothelial growth factor (VEGF) usually existed in high levels in ruptured tendons while its levels were negligible in adult Achilles tendon. This angiogenic peptide can increase the vascularity (Pufe et al., 2001).

In the present work the experimentally ruptured tendon, cxhibited, numerous, swollen rounded or oval cells with large euchromatic nuclei surrounded by granular cytoplasm. Nuclei had prominent nuclcolus and showed different stages of milosis. Yamamoto et al. (2002) noticed active tenocytes in Achilles tendon of rabbits following collagenase induced injury. This active tenocytes aid healing or increase the glycosaminoglycans content of matrix.

The ultrastructural studies in the present work, further clarified that in experimentally ruptured tendons various forms of fibroblasts were observed. Some fibroblasts had elongated nuclei, and their cytoplasmic processes contained dilated cisterns of rough endoplasmic reticulum with detached ribosomes. Other fibroblasts had rounded nuclei and their cytoplasmic processes contained degenerated ill-defined cisterns of rough cndoplasmic reticulum. Among the degenerated collagen fibers few fibroblasts had irregular nuclear nembrane, promincnt nucleolus, and degenerated ill-defined cytoplasmic processes. The presence of rounded nuclei and prominent nuclcoli suggest active protein synthesis and activity of fibroblasts (Tallon et al., 2001). The presence of signs of activily in the nuclcus simultaneously with signs of degeneration in the cytoplasmic processes might reveal that fibroblasts pass through a stage of activity in attempt of repair or healing, followed by exhaustion and degeneration. This results suggest that healing of ruputered tendons might require medical trealment like vandate ingcstion to promote rapid organization of collagen bundles (Mover et al., 2003). operative treatment to promote parallel orientation of collagen 
(Thermann et al., 2002) or local delivery of growth and differentiation factor 5 by coated sutures to allow induction of tendon-like cells (Rickert et al., 2001).

In conclusion, the present work clarified that aging caused degenerative changes in both collagen fibers and fibroblasts while steroid administration and experimental rupture caused noticeable vascularity and degeneration of collagen fibers and alteration in the fibroblasts. The determination of degrec of degeneration of collagen fibers and the morphological changes in the fibroblasts might be beneficial in determination of the type of treatment whether medical or surgical and could help in the selection of postoperative regulations required to promote healing.

\section{SUMMARY}

The present study aimed to demonstrate the ultrastructure of the Achilles tendon in rat and to compare the degenerative changes resulting from aging, the changes following steroid administration with the degenerative changes produced in experimentally ruptured tendons.

The results revealed that the Achilles tendon of adult rat was formed of dense regular elongated collagen fibers with interposed libroblasts. The fibroblasts had cuchromatic clongated nuclei and numerous cytoplasmic processes with extensive rough endoplasmic reticulum.

The senile tendons showed loose, collagen bundles and irregular arrangement of fibroblasts with cytoplasmic processes containing areas of degeneration. Some tendon cells exhibited nuclei with marked chromatin condensation and restricted cytoplasmic organelles apart from collection of polyribosomes and vesicles.

Following steroid administration the tendons were highly vascular and manifested mast cell infiltration. Wide areas of degeneration and exudation were noticed. Collagen fibrils were thin and partially fragmented. The fibroblasts had crenated nuclei and the cytoplasmic processes exhibited scanty cistems of rough endoplasmic reticulum and numerous lysosomes. Some altered tendon cells were surrounded by strips of extracellular matrix. The cells were occissionally binucleated and their cytoplasm elaborated arched processes.

Experimentally-ruptured tendon were highly vascular and hypercellular. The fibers were interrupted and widely separated with focal areas of condensed collagen. The cells were swollen. showing large rounded nuclei, prominent nucleoli and various mitotic figures.

It was concluded that the determination of degree of degeneration of collagen fibers and the morphological changes in tibroblasts might be beneficial in determi- 
nation of type of treatment whether medical or surgical, and also in the selection of postoperative regulations required to promote healing.

\section{REFERENCES}

1. Ackermann, P.W.; Li, J.; Finn, A. and Ahmed Mad Kericbergs, A. (2001) : Autonomic innervations of tendons, ligaments and joint capsules. A morphologic and quantitative study in the rat. J. Orthop. Res., $19(3): 372$ - 378.

2. Benjamin, H.; Qin, S. and Ralphs, J.R. (1995) : Fibrocartilage associated with human tendons and their pulleys. J. Anat., $187: 625-633$.

3. Benjamin, M.; Tyers, R.N.S. and Ralphs, .I.R. (1991) : Age related changes in tendon fibrocartilage. J. Anat., $179: 127-136$.

4. Brik, D.E. and Zycband, E. (1994) : Assembly of the tendon extra cellular matrix during development. J. Anat., $184: 457$ - 463.

5. Cetti, R.; Junged, D. and Vyberg, M. (1993) : Spontaneous rupture of the Achilles tendon is preceded by wide spread and bilateral tendon damage and ipsilateral inflammation : a clinical and histopathologic study of 60 patients. Acta Orthop. Scand., 74 (1) : $78-84$.

6. Friedrich, T.; Schmidt, W.; Jungmichel, D.; Horn, L.C. and Josten, C. (2001) : Histopathology in rabbit Achilles tendon after operative tenolysis longitudinal fiber incisions. Scand J. Med. Sci Sports, 11 (1) : 4 - 8.

7. Harwood, F.L. and Amiel, D. (1992) : Differential metabolic responses of periarticular ligaments and tendon to joint immobilization. J. Appl. phys., 72 : 1687 1691.

8. Hersh, B.1. and Heath, N.S. (2002) : Achilles tendon rupture as a result of oral steroid therapy. J. Am Pediat. Med. Assoc., 92 (6) : 335 - 338.

9. Hestin, D.; Mainard, D.; Pere, P.; Bellou, A.; Renoult, E.; Cao Huu, T.; Chaniliau, J. and Kessler, M. (1993) : Spontaneous bilateral Achilles rupture in a renal transplanted recipient. Nephron, $65: 491-492$.

10. Junqueira, L.C. and Carneiro, J. (2003) : Lange medical book. Basic Histology Text and Atlas 10th $\mathrm{cd}$. Mc. Graw-Hill Middlc east edition, pp. $101-102$.

11. Khurana, R.; Torzillo, P.J.; Horsley, M. and Mahoney, J. (2002) : Spontaneous bilateral ruplurc of Achilles tendon in paticnt with chronic obstructive plumonary diseasc. Respiratory, 7 (2) : $161-163$. 
12. Maffulli, N.; Waterson, S.W. and Ewen, S.W. (2002) : Ruptured Achilles tendons show increased lectin stainablility. Med Sci Sports Exerc., 34 (7) : 1057 1064 .

13. Mathi, A.S.; Chan, V.; Gryszkiewiz, H.; Adamson, R.T. and Freidman, G.S. (2003) : Levofloxacin associated Achilles tendon rupture. Ann pharmacother, 37 : 1014 - 1017.

14. Martin, .F.; Carison, C.S.; Berry, J. Rebouss in B.A. Gardan, E.S. and Smith, B.P. (1999) : Effect of injected versus iontophoretic corticosteroid on the rabbit tendon. South Med. J., 92 (6) : 600 - 608.

15. Mazzone, H,F. and Mc Cue, T. (2002) : Common conditions of the Achilles tendon. Am. Fam. Physician, 65 (9) : 1805 - 1810.

16. Mc Neilly, C.M.; Banes, A.J.; Benyamin, M. and Ralphs, J.R. (1996) : Ten, don cells in vivo form a three dimensional net work of cell processes linked by gap junctions. J. Anat.. 189 : 594 - 600.

17. Maccellan, D. and Maffulli, N. (2002) : Percutaneous repair of ruptured Achilles tendon. J. Roy. Coll. Surg. (Edinburgh), $47: 613$ - 618.

18. Moyer, K.E.; Saba, A.A.; Hauck, R.M. and Ehrlich, P. (2003) : Systemic vandate ingestion modulates rat tendon repair. Exp. Mol. Pathol., 75 (1) : 80 - 81.

19. Poon, C.C. and Sundaram, N.A. (1997) : Spontancaus bilateral Achills tendon rupture associated with Ciprofloxacin, Med. J. Aust., 166 (12) : 665.

20. Pufe, T.; Petersen, W.; Tillmonn, B. and Mentlein, R. (2002) : The angiogenic peptide vascular and endothelial growth factor is expressed in fetal and ruptured tendons. Virchows Arch., 439 (4) : 579 - 585.

21. Ralphs, J.R.; Benyamin, M. And Thornett, A. (1991) : Cell and matrix biology of the suprapattella in the rat. A structural and immunocytochemical study of fibrocartilage in a tendon subject to compression. Anat. Rec., $231: 167$ - 177.

22. Ralphs, J.R.; Benjamin, M.; Waggelli, A.D.; Russell, D.C.; Messner, K. and Gao, J. (1998) : Regional differences in cell shape and gap junction expression in rat Achilles tendon : relation to fibrocrtilage differentiation. J. Anat.., $193: 215$ 222.

23. Reynolds, E.S. (1963) : The use of lead citrate or high phasan electron opaque stain in electron microscopy. J. cell Biol.. $17: 208-212$.

24. Rickert, M.; Jung, M.; Adlyaman, M.; Richter, W. and Sinnak, H.G. (2001) : A growth and differentiation factor 5 (GDF - 5) coated suture stimulate tendon healing in an Achilles tendon model in rats. Growth factors, 19 (2) : 115 126. 
25. Schepsis, A.A.; Jones, H. and Haas, S.L. (2002) : Achilles tendon disorders in athletes. Am. J. Sport. Med., 30 (2) : 287 - 305.

26. Tallon, C.; Maffulli, N. and Ewen, S.W. (2001) : Ruptured Achilles tendon are significantly more degenerated than tendinopathic tendons. Med. Sci. Sports Exerc., 33 (12) : 1983 - 1990.

27. Thermann, H.; Frerichs, O.; Holch, M. and Biewanes, A. (2002) : Healing of Achilles tendon, an experimental study. Foot-Ankle-Int., 23 (7) : 606 - 613.

28. Vogel, K.G.; Ordog, A.; Pogany, G. and Olah, J. (1993) : Proteoglycans in the compressed region of human tibialis posterior tendon and in ligaments. J. of Orthop. Res., $11: 68-77$.

29. Williams, P.L.; Bannister, L.H.; Berry, M.M.; Collins, P.; Dyson, M.; Dussek, J.E. and Ferguson, M.W.J. (1995) : Gray's Anatomy : The Anatomical basis of medicine and surgery. $38^{\mathrm{hh}}$ Ed. Churchill Living Stone., pp. 886 - 898.

30. Yamamoto, E.; Hata, D.; Kobayashi, A.; Ueda, H.; Tang Kwattana, P.; Okawa, M. and Takehana, K. (2002) : Effect of beta aminopropiontrile and hyaluronic acid on repair of collagenase - induced injury of the rabbit Achilles tendon. J. Comp. Pathol., 126 (2 - 3) : 161 - 170. 


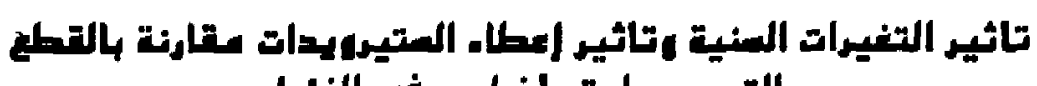
التجريبه لوتر اخيليس الغى النفران

$$
\text { ثميرة يه ست - سميم إبراهيم مالع - عزة ملاع سليهان }
$$

تهدف هذه الاراسة إلى إيضاح التركيب البنانى الدقيق لهتر أخيليس فى النأر ـ

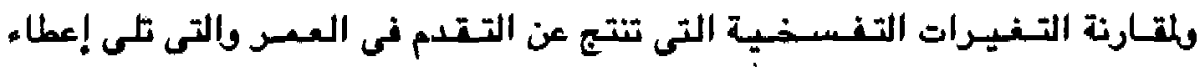

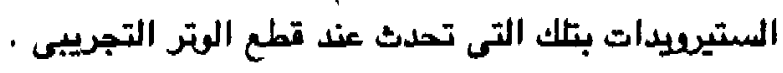

قته أظهرت النتائج أن وتر أخيليس فى النأر البالغ يتكن من ألياف كولاجينية

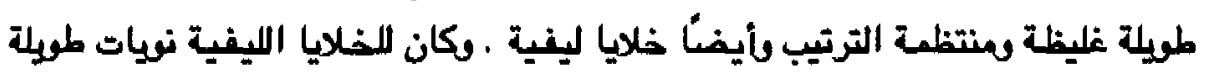

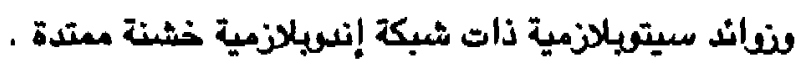

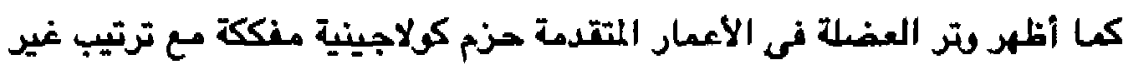

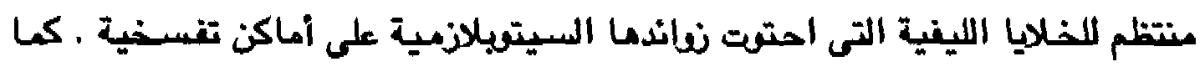

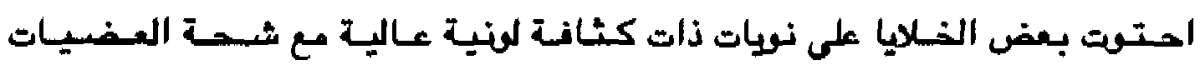

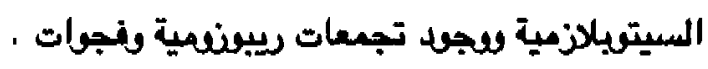

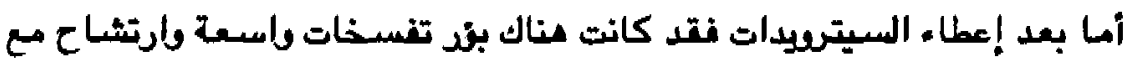

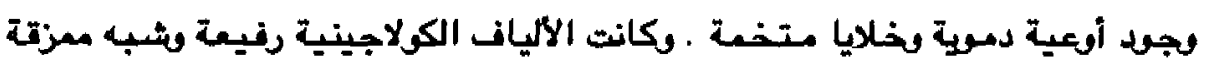

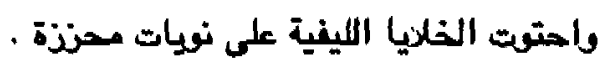

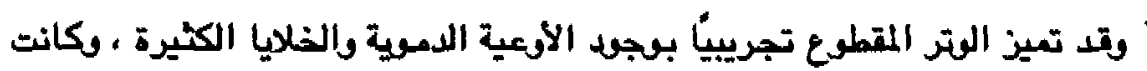

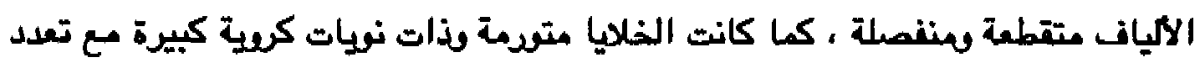

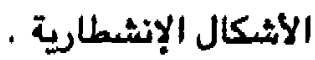


وقد استتيج أن إدراك مدى التفسخ فى الأليات الكولاجينية والتغيرات فى الخلايا

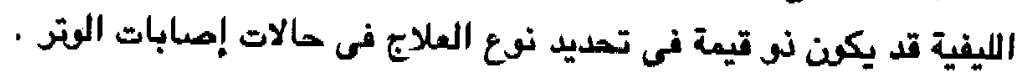

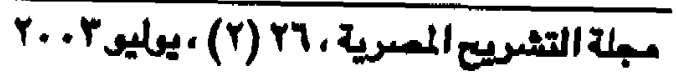

